A/history of the

Collegiate Church

and Cathedral,

1421 to the present.
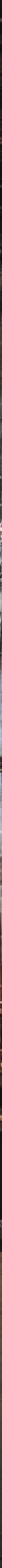


\title{
MANCHESTER CATHEDRAL
}

\author{
$\ddagger$
}

धिद्धि,

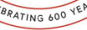

\section{MANCHESTER 1824}

Manchester University Press 
Jeremy Gregory - 9781526161277 Downloaded from manchesterhive.com at 04/26/2023 02:54:13AM via free access 


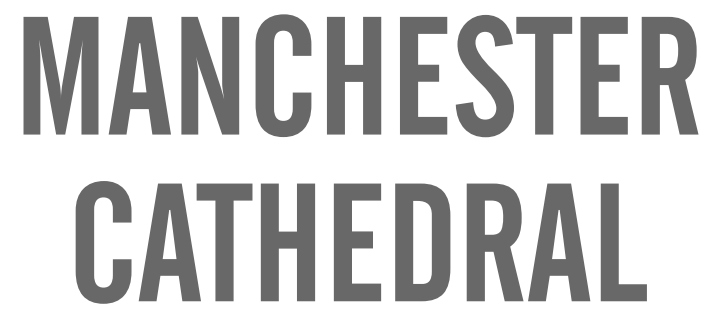

\author{
A history of the \\ Collegiate Church \\ and Cathedral, \\ 1421 to the present \\ 廿
}

Edited by

JEREMY GREGORY

Manchester University Press 
Copyright (C) Manchester University Press 202I

While copyright in the volume as a whole is vested in Manchester University Press, copyright in individual chapters belongs to their respective authors, and no chapter may be reproduced wholly or in part without the express permission in writing of both author and publisher.

Published by Manchester University Press Oxford Road, Manchester MI3 9PL

www.manchesteruniversitypress.co.uk

This publication was made possible thanks to the generous support of the Friends of Manchester Cathedral

British Library Cataloguing-in-Publication Data

A catalogue record for this book is available from the British Library

ISBN 978 I 526I 6I26 o hardback

First published 202I

The publisher has no responsibility for the persistence or accuracy of URLs for any external or third-party internet websites referred to in this book, and does not guarantee that any content on such websites is, or will remain, accurate or appropriate.

Front cover image: courtesy of Manchester Cathedral

Cover design: www.ironicitalics.com

Typeset in Great Britain by Dave Rodgers 